\title{
Spatial Distribution of Selected Heavy Metals in Surface Sediments of the EEZ of the East Coast of Peninsular Malaysia
}

\author{
Hasrizal Shaari, ${ }^{1}$ Siti Nurul Hidayu Mohamad Azmi, ${ }^{1}$ Khawar Sultan, \\ Joseph Bidai, $^{2}$ and Yuzwan Mohamad ${ }^{1}$ \\ ${ }^{1}$ School of Marine and Environmental Science, Universiti Malaysia Terengganu, 21030 Kuala Terengganu, Terengganu, Malaysia \\ ${ }^{2}$ Institute of Oceanography and Environment, Universiti Malaysia Terengganu, 21030 Kuala Terengganu, Terengganu, Malaysia \\ Correspondence should be addressed to Hasrizal Shaari; riz@umt.edu.my
}

Received 28 February 2015; Revised 4 May 2015; Accepted 12 May 2015

Academic Editor: Xosé Anton Álvarez-Salgado

Copyright (C) 2015 Hasrizal Shaari et al. This is an open access article distributed under the Creative Commons Attribution License, which permits unrestricted use, distribution, and reproduction in any medium, provided the original work is properly cited.

Spatial distribution of selected metals ( $\mathrm{Al}, \mathrm{Fe}, \mathrm{Mn}, \mathrm{Zn}, \mathrm{Cu}$, and $\mathrm{Co}$ ) in surface sediments in the EEZ of the east coast of Peninsular Malaysia was investigated. The aim of this paper is to determine the distribution pattern and pollution status of heavy metals in tropical shelf sediments since limited information is available. Heavy metal concentrations ranged between 207.58 and $491.33 \mu \mathrm{g} \cdot \mathrm{g}^{-1}$ for $\mathrm{Mn}, 36.13$ and $125.93 \mu \mathrm{g} \cdot \mathrm{g}^{-1}$ for $\mathrm{Zn}, 14.49$ and $22.33 \mu \mathrm{g} \cdot \mathrm{g}^{-1}$ for $\mathrm{Cu}, 2.00$ and $11.12 \mu \mathrm{g} \cdot \mathrm{g}^{-1}$ for $\mathrm{Co}, 6.20$ and $8.95 \%$ for $\mathrm{Fe}$, and 0.94 and $6.62 \%$ for $\mathrm{Al}$. The mean concentrations of heavy metals are in decreasing order as follows: $\mathrm{Fe}>\mathrm{Al}>\mathrm{Mn}>\mathrm{Zn}>\mathrm{Cu}>\mathrm{Co}$. Most metals registered low concentrations at the nearshore areas. Pearson correlation indicates that most of the metals are derived from the miscellaneous sources. Based on the EFs and Igeo, it is implied that the surface sediment trace metal levels in the study area might be enriched by anthropogenic sources. However, the PLI suggests that this area is not contaminated from the measured heavy metals. This work is important to register the current levels of metals so that any change in concentration can be monitored and managed.

\section{Introduction}

The exclusive economic zone (EEZ) of the east coast of Peninsular Malaysia that lies in the Sunda Shelf receives enormous sediment input from rivers under the monsoon type tropical climate. Heavy metals in marine sediments originate primarily from natural (riverine discharge) and anthropogenic (coastal human settlements) sources and are subject to both continental and marine control. When heavy metals enter the marine environment, the distribution is influenced by various physicochemical factors (e.g., sedimentary processes, mineralogical composition, hydrodynamic transport, redox conditions, and biological uptake). Significant amounts of pollutants are received by marine ecosystem every year via several pathways such as heavy industry processes, agriculture, aquaculture, untreated domestic waste, atmospheric emission, and shipping activities. Heavy metals are considered to be contaminants when human activity raises their concentrations in the environment exceeding natural levels [1].
Studies dealing with heavy metals in the EEZ of the east coast of Peninsular Malaysia are very limited [2-5]. Unfortunately, there is only one study that covered the area until the edge of the east coast of Peninsular Malaysia EEZ [2]. Most of the works have focused on specific area such as coastal waters [3-6], mangrove forest [7-9], and river-estuary [10-12]. Hence, it is important to understand the spatial distribution and concentration of metals in the study area. In this study, authors investigated the distribution of selected heavy metals and the pollution status and source of the heavy metals in the study area using environmental assessment indexes: pollution load index (PLI) [13, 14], enrichment factor (EF) $[15,16]$, and index of geoaccumulation (Igeo) [17, 18]. This study will be useful in environmental management by enlightening policy makers about the heavy metal issues in this crucial region.

\section{Materials and Methods}

2.1. Environmental Setting. The EEZ of the east coast of Peninsular Malaysia covers an area from $1^{\circ} 14.047^{\prime}$ to $7^{\circ} 48.92^{\prime} \mathrm{N}$ 


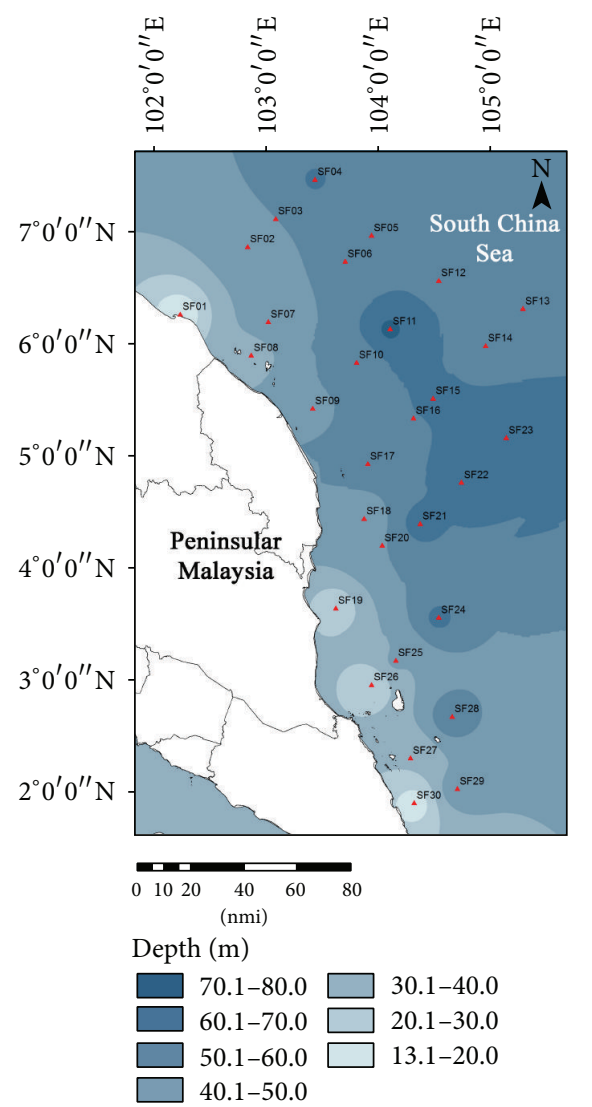

FIGURE 1: Map showing the location of sampling stations in the study area.

latitude and $102^{\circ} 5.03^{\prime}$ to $105^{\circ} 48.77^{\prime} \mathrm{E}$ longitude and is about $130,000 \mathrm{~km}^{2}$ [19] located at the edge of the Indo-West Pacific (Figure 1). During the northeast monsoon, lower temperature and salinity are recorded due to the heavy rainfall and lower solar radiation [20]. Strong current flows close to the Peninsular Malaysia landmass in the northeast and southwest monsoons [21] and, therefore, controls sediment movement [22]. The water circulation is predominantly cyclonic during the northeast monsoon in the winter and anticyclonic during the southeast monsoon in summer [21]. The nearshore areas are influenced by the influx of several rivers (i.e., Kelantan River, Terengganu River, Kemaman River, Pahang River, and Pontian River).

2.2. Sample Collection and Preservation. Surface sediments from 30 sampling stations were collected during the cruise in June 2008 aboard the Department of Fisheries, Malaysia, KL Paus using Smith McIntyre Grab sampler (Figure 1). The water depths of the sampling locations ranged from 13.0 to 72.0 meters (Table 1). Sediments of the upper $5 \mathrm{~cm}$ were collected with a plastic spoon and stored in clean vinyl bags to prevent possible contamination. The sediment samples were oven-dried at $50^{\circ} \mathrm{C}$ and passed through a $2 \mathrm{~mm}$ sieve. From the bulk sediment, a representative subsample was powdered and homogenized in an agate mortar with a pestle for further analysis.
TABLE 1: The coordinates of each sampling station.

\begin{tabular}{|c|c|c|c|}
\hline Station & Latitude & Longitude & Depth (m) \\
\hline SF01 & $06^{\circ} 13.99^{\prime} \mathrm{N}$ & $102^{\circ} 19.00^{\prime} \mathrm{E}$ & 13 \\
\hline SF02 & $06^{\circ} 50.04^{\prime} \mathrm{N}$ & $102^{\circ} 47.04^{\prime} \mathrm{E}$ & 46.5 \\
\hline SF03 & $07^{\circ} 05.03^{\prime} \mathrm{N}$ & $103^{\circ} 04.99^{\prime} \mathrm{E}$ & 50 \\
\hline SF04 & $07^{\circ} 25.98^{\prime} \mathrm{N}$ & $103^{\circ} 26.01^{\prime} \mathrm{E}$ & 61 \\
\hline SF05 & $06^{\circ} 56.09^{\prime} \mathrm{N}$ & $103^{\circ} 56.04^{\prime} \mathrm{E}$ & 52 \\
\hline SF06 & $06^{\circ} 42.14^{\prime} \mathrm{N}$ & $103^{\circ} 35.17^{\prime} \mathrm{E}$ & 52 \\
\hline SF07 & $06^{\circ} 10.00^{\prime} \mathrm{N}$ & $103^{\circ} 01.00^{\prime} \mathrm{E}$ & 45 \\
\hline SF08 & $05^{\circ} 52.10^{\prime} \mathrm{N}$ & $102^{\circ} 51.92^{\prime} \mathrm{E}$ & 34 \\
\hline SF09 & $05^{\circ} 22.06^{\prime} \mathrm{N}$ & $102^{\circ} 21.97^{\prime} \mathrm{E}$ & 47 \\
\hline SF10 & $05^{\circ} 48.20^{\prime} \mathrm{N}$ & $103^{\circ} 48.98^{\prime} \mathrm{E}$ & 55 \\
\hline SF11 & $06^{\circ} 06.16^{\prime} \mathrm{N}$ & $104^{\circ} 09.11^{\prime} \mathrm{E}$ & 72 \\
\hline SF12 & $06^{\circ} 32.01^{\prime} \mathrm{N}$ & $104^{\circ} 22.11^{\prime} \mathrm{E}$ & 59 \\
\hline SF13 & $06^{\circ} 16.98^{\prime} \mathrm{N}$ & $105^{\circ} 16.99^{\prime} \mathrm{E}$ & 55 \\
\hline SF14 & $05^{\circ} 57.15^{\prime} \mathrm{N}$ & $104^{\circ} 58.13^{\prime} \mathrm{E}$ & 56 \\
\hline SE15 & $05^{\circ} 29.08^{\prime} \mathrm{N}$ & $104^{\circ} 29.02^{\prime} \mathrm{E}$ & 60 \\
\hline SF16 & $05^{\circ} 18.50^{\prime} \mathrm{N}$ & $104^{\circ} 12.60^{\prime} \mathrm{E}$ & 60 \\
\hline SF17 & $04^{\circ} 54.12^{\prime} \mathrm{N}$ & $103^{\circ} 42.98^{\prime} \mathrm{E}$ & 54 \\
\hline SF18 & $04^{\circ} 28.14^{\prime} \mathrm{N}$ & $103^{\circ} 49.98^{\prime} \mathrm{E}$ & 40 \\
\hline SF19 & $03^{\circ} 37.07^{\prime} \mathrm{N}$ & $103^{\circ} 41.08^{\prime} \mathrm{E}$ & 23 \\
\hline SF20 & $03^{\circ} 55.10^{\prime} \mathrm{N}$ & $104^{\circ} 00.05^{\prime} \mathrm{E}$ & 50 \\
\hline SF21 & $04^{\circ} 22.16^{\prime} \mathrm{N}$ & $104^{\circ} 22.07^{\prime} \mathrm{E}$ & 65 \\
\hline SF22 & $04^{\circ} 44.19^{\prime} \mathrm{N}$ & $104^{\circ} 38.44^{\prime} \mathrm{E}$ & 66 \\
\hline SF23 & $05^{\circ} 08.10^{\prime} \mathrm{N}$ & $105^{\circ} 12.90^{\prime} \mathrm{E}$ & 67 \\
\hline SF24 & $03^{\circ} 32.08^{\prime} \mathrm{N}$ & $104^{\circ} 36.00^{\prime} \mathrm{E}$ & 62 \\
\hline SF25 & $03^{\circ} 09.14^{\prime} \mathrm{N}$ & $104^{\circ} 09.04^{\prime} \mathrm{E}$ & 41 \\
\hline SF26 & $02^{\circ} 56.13^{\prime} \mathrm{N}$ & $103^{\circ} 49.97^{\prime} \mathrm{E}$ & 20 \\
\hline SF27 & $02^{\circ} 16.94^{\prime} \mathrm{N}$ & $104^{\circ} 16.97^{\prime} \mathrm{E}$ & 30 \\
\hline SF28 & $02^{\circ} 39.18^{\prime} \mathrm{N}$ & $104^{\circ} 38.91^{\prime} \mathrm{E}$ & 58 \\
\hline SF29 & $02^{\circ} 00.55^{\prime} \mathrm{N}$ & $104^{\circ} 41.97^{\prime} \mathrm{E}$ & 46 \\
\hline SF30 & $01^{\circ} 48.04^{\prime} \mathrm{N}$ & $104^{\circ} 15.03^{\prime} \mathrm{E}$ & 14 \\
\hline
\end{tabular}

2.3. Analytical Procedure. Approximately $0.05 \mathrm{~g}$ of homogenized sample was digested in a sealed Teflon vessel with $1.5 \mathrm{~mL}$ mixed concentrated acids $\left(2 \mathrm{HF}: 3 \mathrm{HNO}_{3}: 3 \mathrm{HCl}\right)$ $[23,24]$ with some modifications. The Teflon vessels were heated at $150^{\circ} \mathrm{C}$ for 7 hours. A clear solution with no residue was obtained at this stage. After cooling to room temperature, the digested solution in the Teflon vessel was transferred into a $15 \mathrm{~mL}$ polypropylene test tube and diluted with $10 \mathrm{~mL}$ high purity deionized water. An inductively coupled plasma mass spectrometer (ICP-MS; model 6200 Perkin Elmer Ltd.) was used for the determinations of $\mathrm{Al}, \mathrm{Fe}, \mathrm{Cu}, \mathrm{Mn}, \mathrm{Zn}$, and Co. The accuracy was examined by analyzing in duplicate a Canadian Certified Reference Materials Project standard (NBS 1646a). All glassware and Teflon sample cups in this study were soaked in nitric acid of 5\% overnight, rinsed with distilled water, and oven-dried to eliminate potential contamination as part of the QA/QC program.

2.4. Enrichment Factor (EF). This method normalises the measured metal concentration with respect to a reference metal and is frequently used as an indicator for pollution [15, 16]. The continental shale abundance metal concentrations [1] were used as the background metal contents. Aluminium is 
TABLE 2: Classification of EF.

\begin{tabular}{lc}
\hline EF value & Classification \\
\hline $\mathrm{EF}<1$ & No enrichment \\
$\mathrm{EF}<3$ & Minor enrichment \\
$\mathrm{EF}=3-5$ & Moderate enrichment \\
$\mathrm{EF}=5-10$ & Moderately severe enrichment \\
$\mathrm{EF}=10-25$, & Severe enrichment \\
$\mathrm{EF}=25-50$ & Very severe enrichment \\
$\mathrm{EF}>50$ & Extremely severe enrichment \\
\hline
\end{tabular}

used as a reference element because of its conservative nature [25-28]. Also, Al is a major constituent of clay mineral [2931] and has been used as a reference element to assess the status of heavy metals pollution for some environments in Malaysia $[4,6,32]$. The EF was calculated using the relation proposed by Sutherland [15] and expressed as

$$
\mathrm{EF}=\frac{[\mathrm{Cn} / \mathrm{Cref}]}{[\mathrm{Bn} / \mathrm{Bref}]},
$$

where $\mathrm{Cn}$ is content of the examined element in the examined environment, Cref is content of the examined element in the reference environment, $\mathrm{Bn}$ is content of the reference element in the examined environment, and Bref is content of the reference element in the reference environment. The categories of EF were proposed by Sutherland [15] as described in Table 2.

2.5. Index of Geoaccumulation Index (Igeo). Igeo is generally used to compare the status of heavy metal concentration with the background values. Igeo can describe the relationship between the measured element in the sediment fraction and the geochemical value in fossil argillaceous sediment or average shales [1]. This index was calculated using the formula suggested by Müller [33]:

$$
\text { Igeo }=\log _{2}\left[\frac{\mathrm{Cn}}{1.5 \mathrm{Bn}}\right]
$$

where $\mathrm{Cn}$ is the measured concentration of the element in soil or sediment and $\mathrm{Bn}$ is the geochemical background value. The constant value, 1.5 , is background matrix correction factor due to the lithological variations. Müller [17] proposed the following descriptive classes for the Igeo values (Table 3).

2.6. Pollution Load Index (PLI). This index is widely used as a simple and comparative way to evaluate the degree of heavy metal pollution in marine sediment $[13,14]$. This index is derived from the contamination factor (CF) that was proposed by Müller [17]. The background values of metals in this study are the average values of continental shale [1]. The CF ratio was estimated by dividing the concentration of each metal in the soil by the baseline/background value [14]:

$$
\mathrm{CF}=\frac{\left[C_{\text {heavy metal }}\right]}{\left[C_{\text {background }}\right]} .
$$

The PLI was determined as the root of the product of the $n$ CF:

$$
\mathrm{PLI}=\left(\mathrm{CF}_{1} \times \mathrm{CF}_{2} \times \mathrm{CF}_{3} \times \cdots \times \mathrm{CF}_{n}\right)^{1 / n} .
$$

\begin{tabular}{|c|c|c|}
\hline Igeo & Igeo class & Description of sediment quality \\
\hline$<0$ & 0 & Uncontaminated \\
\hline $0-1$ & 1 & $\begin{array}{l}\text { Uncontaminated to moderately } \\
\text { contaminated }\end{array}$ \\
\hline $1-2$ & 2 & Moderately contaminated \\
\hline $2-3$ & 3 & $\begin{array}{l}\text { Moderately to strongly } \\
\text { contaminated }\end{array}$ \\
\hline $3-4$ & 4 & Strongly contaminated \\
\hline $4-5$ & 5 & $\begin{array}{l}\text { Strongly to extremely strongly } \\
\text { contaminated }\end{array}$ \\
\hline$>5$ & 6 & Extremely contaminated \\
\hline
\end{tabular}

TABLE 3: Classification of geoaccumulation index.

TABLE 4: CF and PLI classification metals.

\begin{tabular}{lc}
\hline CF & Classification \\
\hline 0 & None \\
1 & None to medium \\
2 & Moderate \\
3 & Moderate to strong \\
4 & Strongly polluted \\
5 & Strong to very strong \\
6 & Very strong \\
\hline PLI & Classification \\
\hline$>1$ & Polluted \\
$<1$ & No pollution \\
\hline
\end{tabular}

TABLE 5: The value of accuracy of analysis for standard reference.

\begin{tabular}{lccc}
\hline Metals & $\begin{array}{c}\text { Value of SRM } \\
(\mu \mathrm{g} / \mathrm{g})\end{array}$ & $\begin{array}{c}\text { Value recorded } \\
(\mu \mathrm{g} / \mathrm{g})\end{array}$ & $\begin{array}{c}\text { Accuracy of } \\
\text { analysis } \\
(\%)\end{array}$ \\
\hline $\mathrm{Al}$ & 2.297 & 2.633 & 114.63 \\
$\mathrm{Fe}$ & 2.008 & 2.303 & 114.69 \\
$\mathrm{Cu}$ & 10.01 & 9.8 & 97.03 \\
$\mathrm{Mn}$ & 234.5 & 244.7 & 104.36 \\
$\mathrm{Zn}$ & 48.9 & 43.2 & 88.34 \\
$\mathrm{Co}$ & 5 & 5.280 & 105.60 \\
\hline
\end{tabular}

This empirical index provides a simple, comparative means for assessing the level of heavy metal pollution [13]. The contamination classes based on CF and PLI proposed by Tomlinson et al. [13] are shown in Table 4.

\section{Results and Discussion}

The recovery test coincided with the certified values of NBS 1646a. The recovery percentage of measured metals was found to be acceptable, ranging between $88.34 \%$ and $114.69 \%$ (Table 5).

The selected heavy metal concentrations in the surface sediments from 30 stations varied from 207.58 to $491.33 \mu \mathrm{g} \cdot \mathrm{g}^{-1}$ for $\mathrm{Mn}, 36.13$ to $125.93 \mu \mathrm{g} \cdot \mathrm{g}^{-1}$ for $\mathrm{Zn}, 14.49$ to $22.33 \mu \mathrm{g} \cdot \mathrm{g}^{-1}$ for $\mathrm{Cu}$, and 2.00 to $11.12 \mu \mathrm{g} \cdot \mathrm{g}^{-1}$ for Co (Table 6). The average concentrations of $\mathrm{Mn}, \mathrm{Zn}, \mathrm{Cu}$, and $\mathrm{Co}$ are 
TABLE 6: Heavy metals concentration in each station.

\begin{tabular}{lcccccc}
\hline Station & Al & Fe & Cu & Mn & Zn & Co \\
\hline SF01 & 5.23 & 7.84 & 21.98 & 338.61 & 61.19 & 9.50 \\
SF02 & 5.28 & 7.23 & 22.05 & 332.68 & 62.20 & 9.72 \\
SF03 & 4.77 & 7.36 & 21.07 & 316.10 & 69.58 & 9.52 \\
SF04 & 6.62 & 7.86 & 22.33 & 300.97 & 80.39 & 10.14 \\
SF05 & 4.47 & 7.22 & 19.75 & 346.04 & 62.56 & 9.66 \\
SF06 & 4.78 & 7.74 & 18.57 & 288.24 & 75.69 & 10.08 \\
SF07 & 5.16 & 7.31 & 19.04 & 274.51 & 65.29 & 9.35 \\
SF08 & 4.08 & 7.18 & 18.92 & 272.00 & 63.00 & 9.98 \\
SF09 & 3.86 & 7.51 & 17.41 & 256.86 & 62.94 & 9.24 \\
SF10 & 3.25 & 7.15 & 17.15 & 258.06 & 52.88 & 8.92 \\
SF11 & 5.00 & 7.30 & 17.19 & 296.44 & 62.06 & 9.41 \\
SF12 & 3.76 & 7.32 & 17.09 & 491.33 & 57.03 & 9.19 \\
SF13 & 4.75 & 7.48 & 17.12 & 372.78 & 63.51 & 10.10 \\
SF14 & 3.87 & 7.60 & 17.20 & 248.53 & 73.78 & 11.00 \\
SE15 & 3.27 & 7.31 & 16.41 & 250.00 & 58.73 & 9.43 \\
SF10 & 3.25 & 7.15 & 17.15 & 258.06 & 52.88 & 8.92 \\
SF11 & 5.00 & 7.30 & 17.19 & 296.44 & 62.06 & 9.41 \\
SF12 & 3.76 & 7.32 & 17.09 & 491.33 & 57.03 & 9.19 \\
SF13 & 4.75 & 7.48 & 17.12 & 372.78 & 63.51 & 10.10 \\
SF14 & 3.87 & 7.60 & 17.20 & 248.53 & 73.78 & 11.00 \\
SE15 & 3.27 & 7.31 & 16.41 & 250.00 & 58.73 & 9.43 \\
SF16 & 3.55 & 7.21 & 15.90 & 264.71 & 50.59 & 9.69 \\
SF17 & 4.12 & 7.90 & 16.14 & 239.04 & 62.95 & 9.02 \\
SF18 & 3.30 & 7.05 & 15.51 & 234.38 & 50.78 & 9.12 \\
SF19 & 0.94 & 6.20 & 14.49 & 226.56 & 39.45 & 8.13 \\
SF20 & 3.98 & 7.56 & 15.46 & 248.78 & 57.79 & 9.75 \\
SF21 & 3.66 & 7.39 & 16.13 & 236.79 & 51.27 & 8.86 \\
SF22 & 4.27 & 8.04 & 16.12 & 247.06 & 68.43 & 9.71 \\
SF23 & 5.39 & 8.05 & 16.20 & 240.16 & 79.13 & 10.14 \\
SF24 & 3.98 & 7.92 & 17.63 & 247.06 & 64.31 & 9.39 \\
SF25 & 3.35 & 7.71 & 16.34 & 238.19 & 65.26 & 11.12 \\
SF26 & 4.17 & 7.21 & 14.65 & 207.58 & 36.13 & 8.88 \\
SF27 & 4.15 & 7.94 & 17.08 & 232.14 & 54.37 & 2.00 \\
SF28 & 4.05 & 8.19 & 15.26 & 233.20 & 59.09 & 9.01 \\
SF29 & 4.13 & 8.95 & 17.96 & 223.97 & 125.93 & 9.47 \\
SF30 & 5.59 & 8.09 & 16.40 & 239.92 & 53.98 & 9.44 \\
\hline Average & $\mathbf{4 . 2 3}$ & $\mathbf{7 . 5 6}$ & $\mathbf{1 7 . 4 8}$ & $\mathbf{2 7 3 . 4 2}$ & $\mathbf{6 3 . 0 1}$ & $\mathbf{9 . 3 0}$ \\
\hline The & & $\mathbf{0 . 4 9}$ & $\pm \mathbf{2 . 1 4}$ & $\pm \mathbf{5 7 . 9 2}$ & $\pm \mathbf{1 5 . 4 9}$ & $\pm \mathbf{1 . 5 0}$ \\
\hline
\end{tabular}

The concentration of $\mathrm{Al}$ and $\mathrm{Fe}$ in percentage (\%).

The other elements are in $\mu \mathrm{g} \cdot \mathrm{g}^{-1}$.

$273.42 \pm 57.92 \mu \mathrm{g} \cdot \mathrm{g}^{-1}, 63.01 \pm 15.49 \mu \mathrm{g} \cdot \mathrm{g}^{-1}, 17.48 \pm 2.14 \mu \mathrm{g} \cdot \mathrm{g}^{-1}$, and $9.1 \pm 1.5 \mu \mathrm{g} \cdot \mathrm{g}^{-1}$. Fe and $\mathrm{Al}$ contents vary, respectively, from 6.20 to $8.95 \%$ and from 0.94 to $6.62 \%$, with an average of $7.56 \pm 0.49 \%$ and $4.23 \pm 1.0 \%$ (Table 6 ). The average concentrations of the heavy metals in this study followed the order of $\mathrm{Fe}>\mathrm{Al}>\mathrm{Mn}>\mathrm{Zn}>\mathrm{Cu}>\mathrm{Co}$.

Pearson correlation coefficient matrix was used to distinguish the relationships between observed heavy metals (Table 7). Only two moderate correlations were shown between elements $\mathrm{Zn}-\mathrm{Fe}(r=0.71, p<0.05)$ and $\mathrm{Al}-\mathrm{Cu}$ $(r=0.63, p<0.05)$. The positive correlations indicate that
TABLE 7: Correlation between heavy metals and organic carbon in the study area.

\begin{tabular}{lcccccc}
\hline Elements & $\mathrm{Al}$ & $\mathrm{Fe}$ & $\mathrm{Cu}$ & $\mathrm{Mn}$ & $\mathrm{Zn}$ & $\mathrm{Co}$ \\
\hline $\mathrm{Al}$ & 1.00 & & & & & \\
$\mathrm{Fe}$ & 0.49 & 1.00 & & & & \\
$\mathrm{Cu}$ & 0.63 & 0.10 & 1.00 & & & \\
$\mathrm{Mn}$ & 0.27 & -0.18 & 0.48 & 1.00 & & \\
$\mathrm{Zn}$ & 0.38 & 0.71 & 0.37 & 0.02 & 1.00 & \\
$\mathrm{Co}$ & 0.17 & 0.00 & 0.15 & 0.17 & 0.27 & 1.00 \\
\hline
\end{tabular}

One-way ANOVA; $p<0.05$.

the contents of these metals in the surface sediments probably originated from similar sources [34]. Most of the metals showed a weak correlation between each other $(0<r<0.49$, $p<0.05)$ indicating different sources. Meanwhile, Fe shows a negative correlation with $\mathrm{Mn}(r=-0.18, p<0.05)$ suggesting that both metals maybe originated from different sources [35] or due to the $\mathrm{pH}$-redox sensitive nature of these two major elements their postdepositional concentrations are subject to alteration by the complex biochemical processes. The statistical analysis of one-way ANOVA shows a significant difference in concentration between studied heavy metals.

Sediment Fe levels were higher in the southern sampling locations especially at SF28, SF29, and SF30 (Johor waters). The sources of Fe input in the area are unknown and, therefore, require further research. However, a huge amount of iron source may originate from the iron ore mining activity $[36,37]$ and other anthropogenic sources. The Fe contents in the other sites were also slightly higher than shale average [1]. This is owing to high estimated iron ore reserve in the east coast of Peninsular Malaysia. The iron-rich sedimentary rocks in the mining area of the east coast of Peninsular Malaysia are estimated to be transported via rivers run-off and land run-off [38]. Denton et al. [39] stated that the waste discharges from industrial processes are the potential sources of elevated heavy metals in the environment. Unfortunately, there is no available data of Fe from the river that linked to mining activity to substantiate this idea.

It is noted that concentration of $\mathrm{Al}$ was slightly higher in Kelantan and Johor waters than the other sites. The higher concentration of $\mathrm{Al}$ in those particular areas might be originated from both natural and anthropogenic sources. In the Kelantan area, a higher value of $\mathrm{Al}$ is assigned to the transports of aluminium-rich sediment by the river flow. This metal is commonly found in soil, minerals (e.g., sapphires, rubies, and turquoise), rocks (especially igneous rocks), and clays [40]. Logging and reforestation activities in the upstream areas such as Gua Musang and Lojing may expose the aluminum-rich sedimentary rocks or soils to weathering process and rainwater. The high energy of Kelantan River flow plays a major role in carrying the suspended particles towards the ocean. Meanwhile, the high content of Al in Johor waters might result from the bauxite mining activity in Ramunia Bay. Bauxite is a rock consisting of aluminum hydrate or hydroxide minerals, and it is the principal raw material that is used in the aluminum industry [41]. The aluminium-rich 
TABLE 8: The comparison of heavy metal concentration in this study with other studies.

\begin{tabular}{|c|c|c|c|c|c|c|c|c|}
\hline Number & Area & $\mathrm{Al}$ & $\mathrm{Fe}$ & $\mathrm{Cu}$ & $\mathrm{Zn}$ & $\mathrm{Mn}$ & Co & Reference \\
\hline (1) & $\begin{array}{l}\text { EEZ of the east coast of } \\
\text { Peninsular Malaysia }\end{array}$ & $4.23 \pm 1.0$ & $7.56 \pm 0.49$ & $17.48 \pm 2.14$ & $63.01 \pm 15.47$ & $273.42 \pm 57.92$ & $9.30 \pm 1.5$ & This study \\
\hline (2) & $\begin{array}{l}\text { EEZ of the east coast of } \\
\text { Peninsular Malaysia } \\
\text { (premonsoon) }\end{array}$ & $3.04 \pm 1.4$ & $2.03 \pm 0.45$ & $16.0 \pm 7.2$ & $76.3 \pm 8.3$ & n.a. & n.a. & {$[2]$} \\
\hline (3) & $\begin{array}{l}\text { EEZ of the east coast of } \\
\text { Peninsular Malaysia } \\
\text { (postmonsoon) }\end{array}$ & $4.57 \pm 1.34$ & $1.36 \pm 0.38$ & $15.1 \pm 2.7$ & $56.1 \pm 17.1$ & $269 \pm 80$ & n.a. & {$[2]$} \\
\hline (4) & Strait of Johor & $8.25 \pm 2.49$ & $3.04 \pm 0.67$ & $30.7 \pm 22.5$ & $132.5 \pm 52.6$ & $265 \pm 152$ & $5.8 \pm 1.5$ & {$[52]$} \\
\hline (5) & Strait of Malacca & n.a. & $2.15 \pm 0.59$ & $17.46 \pm 8.08$ & $63.68 \pm 21.93$ & $421 \pm 209$ & n.a. & {$[53]$} \\
\hline (6) & Terengganu River & n.a. & n.a. & n.a. & n.a. & $517.9 \pm 161.8$ & $15.1 \pm 7.4$ & {$[10]$} \\
\hline (7) & Kemaman River & n.a. & n.a. & 48.8 & n.a. & 597.8 & 16.0 & {$[4]$} \\
\hline (8) & Pahang River & n.a & n.a & $18.65 \pm 7.65$ & n.a. & n.a. & n.a. & {$[12]$} \\
\hline (9) & Upper crust, North China & n.a. & n.a. & 25 & 61 & n.a. & 18 & {$[54]$} \\
\hline (10) & Upper continental crust & 7.7 & 3.1 & 14.3 & 52 & 527 & 11.6 & {$[55]$} \\
\hline (11) & Shale average & 8.4 & 4.7 & 45 & 95 & 850 & 19 & {$[1]$} \\
\hline
\end{tabular}

The concentration of $\mathrm{Al}$ and $\mathrm{Fe}$ in percentage (\%).

The other elements are in $\mu \mathrm{g} \cdot \mathrm{g}^{-1}$.

n.a.: not analyzed.

minerals are easier to be transported to the study area via land run-off due to the mining area that is located close to the shoreline [38].

The higher concentration of Mn was observed at the offshore area of Terengganu waters. The distribution pattern of $\mathrm{Mn}$ as determined in the present paper was consistent with that in the previous study [2]. Salomons and Forstner [42] claimed that the chemical composition and diagenesis of sediment could affect metal accumulation process. The concentrations of $\mathrm{Mn}$ at all sites in the study area were relatively lower than the value of river-estuary sediments [10, 11], suggesting that the river discharge may flush the manganeserich sediment from terrestrial into the coastal area. Then, the current dynamic may play a role in dispersing it toward the north and the offshore area. The other major factors that may control the metal distribution are the oxidation of accumulated metals and bioturbation by the benthic organisms [43].

The average $\mathrm{Zn}$ concentration was found to be comparable to the previous reports of Shazili et al. [2] in the sediments of this area. The weathering effects may change those materials into soluble form of $\mathrm{Zn}$ which is released into aquatic environment $[44,45]$. The concentration of $\mathrm{Zn}$ was found to be higher in the surface sediment at site SF29 (Johor waters). The concentrations of this metal in the other sampling sites were almost uniform. We assume that the distribution pattern of $\mathrm{Zn}$ is closely related to the ironrich deposits due to high adsorption between $\mathrm{Zn}$ and $\mathrm{Fe}$ $(r=0.79)$. According to Salomons and Forstner [42], iron hydroxides are able to adsorb large quantities of metals through cation exchange processes, and iron oxides also play an important role in trapping metals in aquatic sediments [46]. The other possible sources of $\mathrm{Zn}$ are from motor oil, grease, phosphate fertilizers, sewage sludge, transmission fluid, undercoating, and concrete [47].

Higher concentration of $\mathrm{Cu}$ was determined in Kelantan waters than the other sampling sites. High correlation between $\mathrm{Cu}$ and $\mathrm{Al}$ is probably due to the same origin and transport and the chemical affinities between them. Naturally, copper can be discharged into the environment from forest fires, weathering process of exposed soil, and decaying vegetation, while anthropogenic source of copper may originate from domestic use of copper-based chemicals, municipal untreated sewage sludge, and corrosion of copper materials. Kelantan River that flows via high-populated urban areas (e.g., Kuala Krai, Tanah Merah, and Kota Bharu) may carry these substances downstream. The other potential source of $\mathrm{Cu}$ in Kelantan waters might be from the leachate of Sabak beach landfill area. The produced leachate that contains soluble form of $\mathrm{Cu}$ [48-50] may permeate into the coastal area.

The concentration of Co was slightly high at SF13, SF14, and SF23 (Terengganu offshore), and the lowest concentration was identified at SF27 (Johor waters). Cobalt may enter the aquatic environment from both natural sources and human activities [51]. Under natural conditions, Co is found in most rocks, soil, water, plants, and animals. The association of Co with $\mathrm{Mn}$ is most likely due to the adsorption on to the Mn-(oxyhydr)oxides and consequent coprecipitation as marine sediments. The anthropogenic sources of cobalt are derived from soils near ore deposits and ore smelting facilities and soils contaminated by airport traffic, highway traffic, or other industrial pollution source [51]. Cobalt may enter aquatic environment via run-off and leaching when rainwater washes through the substances containing cobalt. Thus, the presence of this metal in the studied area possibly derived from the river discharge [48]. This is due to high concentration of Co as reported in the Kerteh mangrove [11], Terengganu River [10], and Pahang River [8].

The comparison of heavy metal compositions was made between the study area and other studies in the region and the crustal values of metals (Table 8). The average concentrations of metals ( $\mathrm{Al}, \mathrm{Cu}, \mathrm{Mn}, \mathrm{Zn}$, and $\mathrm{Co}$ ) are almost similar to initial report by Shazili et al. [2] except for Fe. On average, 
Fe concentration was higher than the regional studies [52, 53], upper continental shelf [54], and shale average [1]. The concentration of $\mathrm{Al}, \mathrm{Cu}, \mathrm{Mn}$, and $\mathrm{Zn}$ seemed to be lower and/or similar with respect to the regional studies $[52,53]$, upper continental crust $[54,55]$, and shale average [1]. In the meantime, Co was comparatively higher than the value of Strait of Johor [52], but it was still lower compared to the river-estuary values $[8,10]$, upper continental crust $[54,55]$, and shale average [1].

The distribution patterns of studied metals significantly varied spatially in the study area, but most of them were consistent with low concentration in nearshore area of Terengganu and Pahang (Figure 2). It seems that current dynamic is not the major factor affecting the distribution of studied metals in this study. But, we are unable to discuss this factor in more detail owing to the absence of current dynamic data such as wave, current, and sediment budget.

Evaluation of Pollution. For a better estimation of the heavy metals status in the surface sediments, the pollution load index (PLI), enrichment factor (EF), and index of geoaccumulation (Igeo) were calculated and discussed. The combination of these indices has been recognized as a powerful tool for assessing the anthropogenic input of heavy metals in different environments [56-58].

The EF was calculated for a better assessment of anthropogenic input for each metal (Table 9). The average EF for Fe (3.51) indicates that the surface sediments in the study area were moderately enriched with this metal [59]. The EF value above 1.5 indicates an anthropogenic contribution [60]. The EF values of $\mathrm{Co}$ (1.1), $\mathrm{Al}$ (1.0), $\mathrm{Cu}$ (0.8), Mn (0.7), $\mathrm{Zn}(0.7)$, and $\mathrm{Pb}(0.4)$ suggest that the sediments have no enrichment with those metals. According to Zhang and Liu [60], if EF is less than 1.5 , the metal concentration is considered crustal or natural weathering origin. EF value close to 1 reflected a crustal origin, while those with a factor more than 10 are considered to have noncrustal sources [7]. The higher the EF values, the more severe the anthropogenic contribution. The highest EF value was recorded at SF19 sampling location for $\mathrm{Fe}$ (11.8). But, the calculated value for Fe at that site might be argued due to the remarkably low $\mathrm{Al}$ content ( $0.94 \%)$. In this study, the studied heavy metals were proven to be between no enrichment and moderately enrichment.

The values of Igeo in the sediment samples are shown in Table 10. The Igeo of $\mathrm{Al}(0.6)$ indicates that it remains in class 1 in all stations, suggesting that the study area is in background value with respect to this metal $[17,33]$. The average value of Igeo for $\mathrm{Co}$ (0.7), $\mathrm{Mn}$ (0.8), $\mathrm{Zn}(0.8), \mathrm{Cu}(0.8)$, and $\mathrm{Fe}(1.0)$ attains class 1 which indicates that sediments were unpolluted to moderately polluted with these metals [13].

The mean CF values for the metals in the study area follow the decreasing order as $\mathrm{Fe}>\mathrm{Zn}>\mathrm{Al}>\mathrm{Co}>\mathrm{Cu}>\mathrm{Mn}$ (Table 11). As similar to EF, the value of Fe (1.6) was slightly higher than the other elements which may probably indicate the elevated Fe from anthropogenic sources into the study area. However, in terms of the total metals contamination, PLI value $<0.5$ implies that the EEZ of the east coast of Peninsular Malaysia was not polluted with the studied heavy metals. Some have proposed that the combination of low CF
TABLE 9: Enrichment factor for each heavy metal in study area.

\begin{tabular}{lllllll}
\hline \multirow{2}{*}{ Station } & & \multicolumn{5}{c}{ Elements } \\
& Al & Fe & Cu & Mn & Zn & Co \\
\hline SF01 & 1.0 & 2.7 & 0.8 & 0.6 & 0.7 & 0.8 \\
SF02 & 1.0 & 2.5 & 0.8 & 0.6 & 0.8 & 0.8 \\
SF03 & 1.0 & 2.8 & 0.8 & 0.7 & 0.8 & 0.9 \\
SF04 & 1.0 & 2.1 & 0.6 & 0.4 & 0.9 & 0.7 \\
SF05 & 1.0 & 2.9 & 0.8 & 0.8 & 0.8 & 1.0 \\
SF06 & 1.0 & 2.9 & 0.7 & 0.6 & 0.9 & 0.9 \\
SF07 & 1.0 & 2.5 & 0.7 & 0.5 & 0.8 & 0.8 \\
SF08 & 1.0 & 3.1 & 0.9 & 0.7 & 0.8 & 1.1 \\
SF09 & 1.0 & 3.5 & 0.8 & 0.7 & 0.7 & 1.1 \\
SF10 & 1.0 & 3.9 & 1.0 & 0.8 & 0.7 & 1.2 \\
SF11 & 1.0 & 2.6 & 0.6 & 0.6 & 0.8 & 0.8 \\
SF12 & 1.0 & 3.5 & 0.8 & 1.3 & 0.7 & 1.1 \\
SF13 & 1.0 & 2.8 & 0.7 & 0.8 & 0.8 & 0.9 \\
SF14 & 1.0 & 3.5 & 0.8 & 0.6 & 0.9 & 1.3 \\
SF15 & 1.0 & 4.0 & 0.9 & 0.8 & 0.7 & 1.3 \\
SF16 & 1.0 & 3.6 & 0.8 & 0.7 & 0.6 & 1.2 \\
SF17 & 1.0 & 3.4 & 0.7 & 0.6 & 0.7 & 1.0 \\
SF18 & 1.0 & 3.8 & 0.9 & 0.7 & 0.6 & 1.2 \\
SF19 & 1.0 & 11.8 & 2.9 & 2.4 & 0.6 & 3.8 \\
SF20 & 1.0 & 3.4 & 0.7 & 0.6 & 0.7 & 1.1 \\
SF21 & 1.0 & 3.6 & 0.8 & 0.6 & 0.6 & 1.1 \\
SF22 & 1.0 & 3.4 & 0.7 & 0.6 & 0.8 & 1.0 \\
SF23 & 1.0 & 2.7 & 0.6 & 0.4 & 0.9 & 0.8 \\
SF24 & 1.0 & 3.6 & 0.8 & 0.6 & 0.7 & 1.0 \\
SF25 & 1.0 & 4.1 & 0.9 & 0.7 & 0.7 & 1.5 \\
SF26 & 1.0 & 3.1 & 0.7 & 0.5 & 0.4 & 0.9 \\
SF27 & 1.0 & 3.4 & 0.8 & 0.6 & 0.6 & 0.2 \\
SF28 & 1.0 & 3.6 & 0.7 & 0.6 & 0.6 & 1.0 \\
SF29 & 1.0 & 3.9 & 0.8 & 0.5 & 1.2 & 1.0 \\
SF30 & 1.0 & 2.6 & 0.5 & 0.4 & 0.6 & 0.7 \\
\hline Average & $\mathbf{1 . 0}$ & 3.5 & $\mathbf{0 . 9}$ & $\mathbf{0 . 7}$ & $\mathbf{0 . 7}$ & $\mathbf{1 . 1}$ \\
\hline & & & & & &
\end{tabular}

$(\mathrm{C}<2)$ and PLI $(<0.1)$ could be categorized as less polluted and/or not polluted $[13,17]$.

\section{Conclusion}

The distribution patterns of investigated metals ( $\mathrm{Al}, \mathrm{Fe}, \mathrm{Cu}$, $\mathrm{Mn}, \mathrm{Zn}$, and Co) varied in the study area, but most of them were consistent with low concentration in nearshore area of Terengganu and Pahang area. The removal of fine sediments away from the nearshore locations seems to be the controlling factor of metal concentrations. The spatial distribution of selected heavy metals varied significantly in surface sediments of the EEZ of the east coast of Peninsular Malaysia. The heavy metals are added to the sediments in the study area by two main pathways, via river discharge and land run-off. Various indices applied suggested that the sources of most measured heavy metals are merely natural in origin with exception of Fe which registered slightly higher levels. The higher content of Fe in the study area is probably derived 


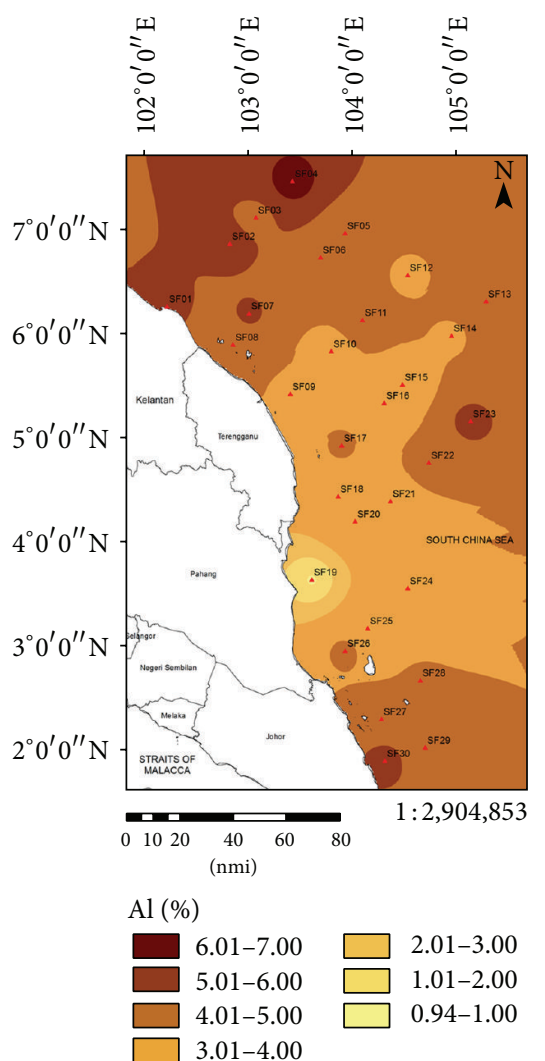

(a)

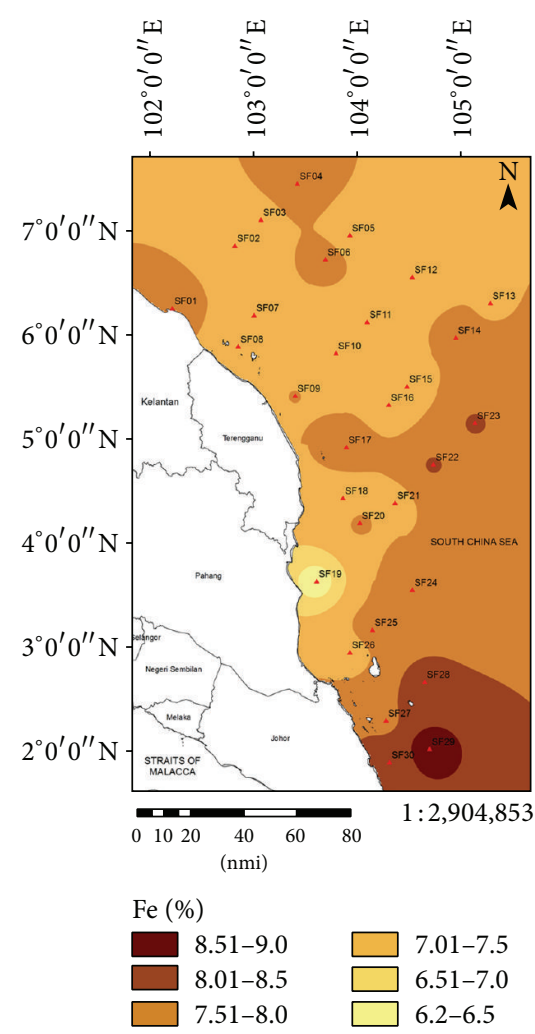

(d)

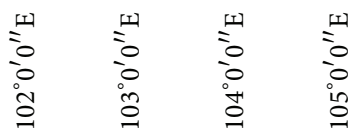

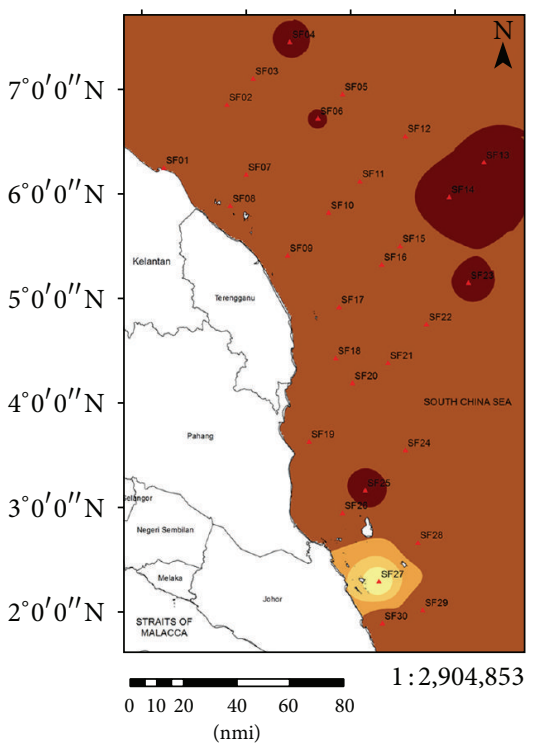

$\operatorname{Co}\left(\mu \mathrm{g} \cdot \mathrm{g}^{-1}\right)$

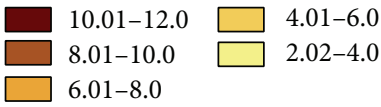

(b)

$\begin{array}{cccc}\text { 푀 } & \text { 푀 } & \text { 푀 } & \text { 푀 } \\ 0 & 0 & 0 & 0 \\ 0 & 0 & 0 & 0 \\ 0 & 0 & 0 \\ 0 & 0 & 0 & 0 \\ 0 & 0 & 0 & 0\end{array}$

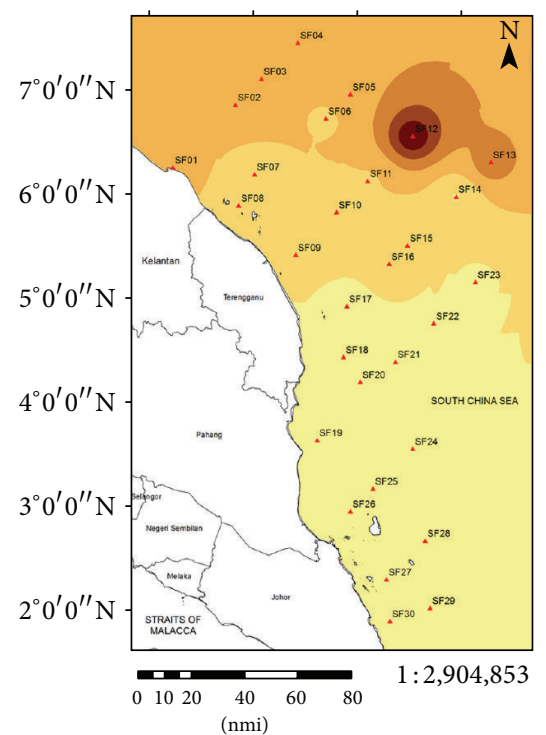

$\operatorname{Mn}\left(\mu \mathrm{g} \cdot \mathrm{g}^{-1}\right)$

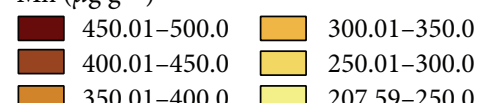

(e)

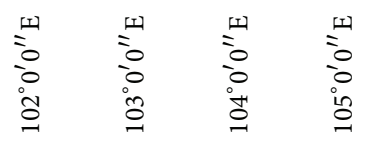

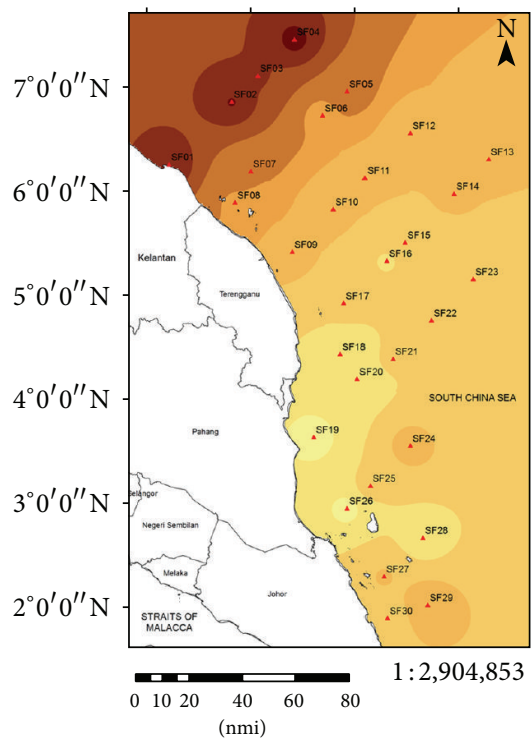

$\mathrm{Cu}\left(\mu \mathrm{g} \cdot \mathrm{g}^{-1}\right)$

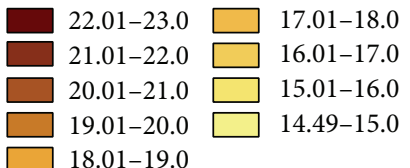

(c)
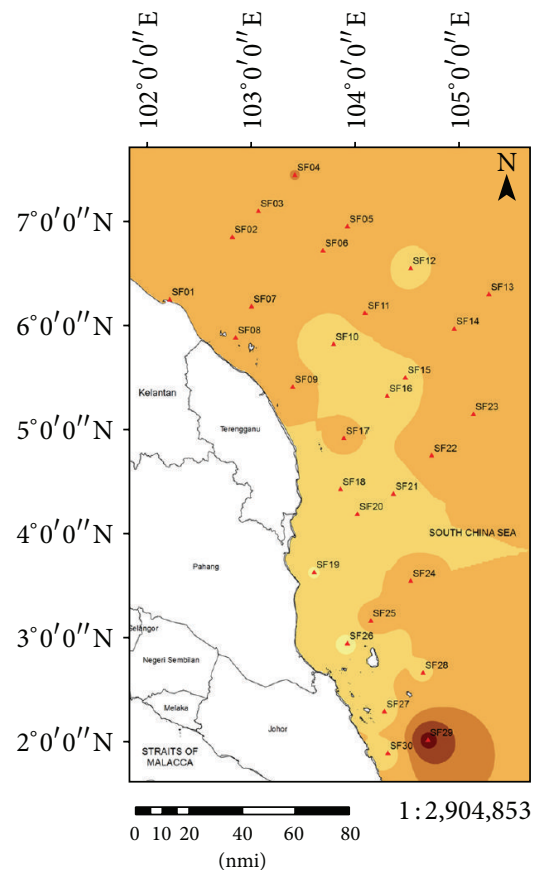

$\mathrm{Zn}\left(\mu \mathrm{g} \cdot \mathrm{g}^{-1}\right)$

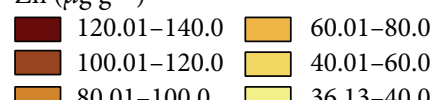

(f)

FIGURE 2: Distribution patterns of heavy metals in the EEZ of the east coast of Peninsular Malaysia. 
TABLE 10: Index of geoaccumulation of heavy metals in the study area.

\begin{tabular}{lllllll}
\hline \multirow{2}{*}{ Station } & & \multicolumn{5}{c}{ Elements } \\
& Al & Fe & Cu & Mn & Zn & Co \\
\hline SF01 & 0.7 & 1.1 & 0.7 & 0.8 & 0.8 & 0.7 \\
SF02 & 0.7 & 1.0 & 0.7 & 0.8 & 0.8 & 0.7 \\
SF03 & 0.6 & 1.0 & 0.7 & 0.8 & 0.9 & 0.7 \\
SF04 & 0.7 & 1.1 & 0.7 & 0.8 & 0.9 & 0.7 \\
SF05 & 0.6 & 1.0 & 0.7 & 0.8 & 0.8 & 0.7 \\
SF06 & 0.6 & 1.0 & 0.7 & 0.8 & 0.9 & 0.7 \\
SF07 & 0.6 & 1.0 & 0.7 & 0.8 & 0.8 & 0.7 \\
SF08 & 0.6 & 1.0 & 0.7 & 0.8 & 0.8 & 0.7 \\
SF09 & 0.5 & 1.0 & 0.7 & 0.8 & 0.8 & 0.7 \\
SF10 & 0.5 & 1.0 & 0.7 & 0.8 & 0.8 & 0.7 \\
SF11 & 0.6 & 1.0 & 0.7 & 0.8 & 0.8 & 0.7 \\
SF12 & 0.5 & 1.0 & 0.7 & 0.9 & 0.8 & 0.7 \\
SF13 & 0.6 & 1.0 & 0.7 & 0.8 & 0.8 & 0.7 \\
SF14 & 0.5 & 1.0 & 0.7 & 0.8 & 0.9 & 0.7 \\
SF15 & 0.5 & 1.0 & 0.7 & 0.8 & 0.8 & 0.7 \\
SF16 & 0.5 & 1.0 & 0.7 & 0.8 & 0.8 & 0.7 \\
SF17 & 0.6 & 1.1 & 0.7 & 0.8 & 0.8 & 0.7 \\
SF18 & 0.5 & 1.0 & 0.7 & 0.8 & 0.8 & 0.7 \\
SF19 & 0.0 & 0.9 & 0.6 & 0.8 & 0.7 & 0.6 \\
SF20 & 0.5 & 1.0 & 0.7 & 0.8 & 0.8 & 0.7 \\
SF21 & 0.5 & 1.0 & 0.7 & 0.8 & 0.8 & 0.7 \\
SF22 & 0.6 & 1.1 & 0.7 & 0.8 & 0.9 & 0.7 \\
SF23 & 0.7 & 1.1 & 0.7 & 0.8 & 0.9 & 0.7 \\
SF24 & 0.5 & 1.1 & 0.7 & 0.8 & 0.8 & 0.7 \\
SF25 & 0.5 & 1.0 & 0.7 & 0.8 & 0.8 & 0.7 \\
SF26 & 0.6 & 1.0 & 0.6 & 0.7 & 0.7 & 0.7 \\
SF27 & 0.6 & 1.1 & 0.7 & 0.8 & 0.8 & 0.2 \\
SF28 & 0.6 & 1.1 & 0.6 & 0.8 & 0.8 & 0.7 \\
SF29 & 0.6 & 1.1 & 0.7 & 0.8 & 1.0 & 0.7 \\
SF30 & 0.7 & 1.1 & 0.7 & 0.8 & 0.8 & 0.7 \\
\hline Average & $\mathbf{0 . 6}$ & $\mathbf{1 . 0}$ & $\mathbf{0 . 7}$ & $\mathbf{0 . 8}$ & $\mathbf{0 . 8}$ & $\mathbf{0 . 7}$ \\
\hline & & & & & &
\end{tabular}

from iron ore mining activities in the east coast of Peninsular Malaysia. Although the study area receives significant input by the anthropogenic sources of $\mathrm{Fe}$, it is negligible compared with polluted areas. The other metals which registered lower concentration than the upper Earth's crustal and shale average value pointing to background levels are trace metals. Thus, we assume that there is not any significant pollutant in the EEZ of the east coast of Peninsular Malaysia. The data from this study will provide valuable information about the current status of heavy metal pollution and as baseline data for the future research in the region as part of continued assessment of metal levels when development along the east coast of Peninsular Malaysia is happening rapidly.

\section{Conflict of Interests}

The authors declare that there is no conflict of interests regarding the publication of this paper.
TABLE 11: Contamination factors (CFs) and pollution load indices (PLIs) of sediment heavy metals in the study area.

\begin{tabular}{llllllll}
\hline Station & & \multicolumn{5}{c}{ Elements } \\
& Al & Fe & Cu & Mn & Zn & Co & PLI \\
\hline SF1 & 0.6 & 1.7 & 0.5 & 0.4 & 0.6 & 0.5 & 0.5 \\
SF2 & 0.6 & 1.5 & 0.5 & 0.4 & 0.7 & 0.5 & 0.5 \\
SF3 & 0.6 & 1.6 & 0.5 & 0.4 & 0.7 & 0.5 & 0.5 \\
SF4 & 0.8 & 1.7 & 0.5 & 0.4 & 0.8 & 0.5 & 0.5 \\
SF5 & 0.5 & 1.5 & 0.4 & 0.4 & 0.7 & 0.5 & 0.5 \\
SF6 & 0.6 & 1.6 & 0.4 & 0.3 & 0.8 & 0.5 & 0.5 \\
SF7 & 0.6 & 1.6 & 0.4 & 0.3 & 0.7 & 0.5 & 0.4 \\
SF8 & 0.5 & 1.5 & 0.4 & 0.3 & 0.7 & 0.5 & 0.4 \\
SF9 & 0.5 & 1.6 & 0.4 & 0.3 & 0.7 & 0.5 & 0.4 \\
SF10 & 0.4 & 1.5 & 0.4 & 0.3 & 0.6 & 0.5 & 0.4 \\
SF11 & 0.6 & 1.6 & 0.4 & 0.3 & 0.7 & 0.5 & 0.4 \\
SF12 & 0.4 & 1.6 & 0.4 & 0.6 & 0.6 & 0.5 & 0.5 \\
SF13 & 0.6 & 1.6 & 0.4 & 0.4 & 0.7 & 0.5 & 0.5 \\
SF14 & 0.5 & 1.6 & 0.4 & 0.3 & 0.8 & 0.6 & 0.4 \\
SF15 & 0.4 & 1.6 & 0.4 & 0.3 & 0.6 & 0.5 & 0.4 \\
SF16 & 0.4 & 1.5 & 0.4 & 0.3 & 0.5 & 0.5 & 0.4 \\
SF17 & 0.5 & 1.7 & 0.4 & 0.3 & 0.7 & 0.5 & 0.4 \\
SF18 & 0.4 & 1.5 & 0.3 & 0.3 & 0.5 & 0.5 & 0.4 \\
SF19 & 0.1 & 1.3 & 0.3 & 0.3 & 0.4 & 0.4 & 0.3 \\
SF20 & 0.5 & 1.6 & 0.3 & 0.3 & 0.6 & 0.5 & 0.4 \\
SF21 & 0.4 & 1.6 & 0.4 & 0.3 & 0.5 & 0.5 & 0.4 \\
SF22 & 0.5 & 1.7 & 0.4 & 0.3 & 0.7 & 0.5 & 0.5 \\
SF23 & 0.6 & 1.7 & 0.4 & 0.3 & 0.8 & 0.5 & 0.5 \\
SF24 & 0.5 & 1.7 & 0.4 & 0.3 & 0.7 & 0.5 & 0.4 \\
SF25 & 0.4 & 1.6 & 0.4 & 0.3 & 0.7 & 0.6 & 0.4 \\
SF26 & 0.5 & 1.5 & 0.3 & 0.2 & 0.4 & 0.5 & 0.4 \\
SF27 & 0.5 & 1.7 & 0.4 & 0.3 & 0.6 & 0.1 & 0.3 \\
SF28 & 0.5 & 1.7 & 0.3 & 0.3 & 0.6 & 0.5 & 0.4 \\
SF29 & 0.5 & 1.9 & 0.4 & 0.3 & 1.3 & 0.5 & 0.5 \\
SF30 & 0.7 & 1.7 & 0.4 & 0.3 & 0.6 & 0.5 & 0.4 \\
\hline Average & $\mathbf{0 . 5}$ & $\mathbf{1 . 6}$ & $\mathbf{0 . 4}$ & $\mathbf{0 . 3}$ & $\mathbf{0 . 7}$ & $\mathbf{0 . 5}$ & $\mathbf{0 . 4}$ \\
\hline & & & & & & &
\end{tabular}

\section{Acknowledgments}

This research was conducted with the joint research from the Ministry of Science, Technology and Innovation (MOSTI) under Science Fund Project (04-03-01-SF0020). The authors wish to express their gratitude to the staffs of Oceanography Laboratory, School of Marine and Environmental Science, and Institute of Oceanography (INOS) and the crew members of KL Paus vessel for their assistance and hospitality throughout the sampling and analytical period.

\section{References}

[1] K. K. Turekian and K. H. Wedepohl, "Distribution of the elements in some major units of the earth's crust," Bulletin of the Geological Society of America, vol. 72, no. 2, pp. 175-192, 1961.

[2] N. A. M. Shazili, M. K. A. Rashid, M. L. Husain, A. Nordin, and S. Ali, "Trace metals in the surface sediments of the South China 
Sea, Area I: Gulf of Thailand and the East Coast of Peninsular Malaysia," in Proceedings of the 1st Technical Seminar on Marine Fishery Resources Survey in the South China Sea Area I: Gulf of Thailand and East Coast of Peninsular Malaysia, pp. 73-85, Southeast Asian Fisheries Development Center, 1999.

[3] H. Shaari, Monsoon effects on the geochemical of surface sediment in the nearshore area off Terengganu, Malaysia [M.S. thesis], Universiti Malaysia Terengganu, Terengganu, Malaysia, 2007.

[4] Y. Kamaruzzaman and M. C. Ong, "Geochemical proxy of some chemical elements in sediments of kemaman river estuary, Terengganu, Malaysia," Sains Malaysiana, vol. 38, no. 5, pp. 631636, 2009.

[5] R. Kh, E. B. Saion, C. K. Yap, M. R. Abdi, and A. Riyahi Bakhtiari, "Vertical distribution of heavy metals and enrichment in the South China Sea sediment cores," International Journal of Environmental Research, vol. 4, no. 4, pp. 877-886, 2010.

[6] N. A. M. Shazili, B. Y. Kamaruzzaman, N. A. Antonina et al., "Interpretation of anthropogenic input of metals in the South China Sea bottom sediments off Terengganu (Malaysia) coastline using $\mathrm{Al}$ as a reference element," Aquatic Ecosystem Health and Management, vol. 10, no. 1, pp. 47-56, 2007.

[7] K. Yunus, H. Shaari, B. I. Mohd Nizam, M. C. Ong, K. C. A. Jalal, and S. Shahbuddin, "Geochemical proxy of sediment cores from Terengganu coastal water, Malaysia," Oriental Journal of Chemistry, vol. 25, no. 1, pp. 9-14, 2009.

[8] K. Yunus, N. Mohd Yusuf, N. A. Mohd Shazili et al., "Heavy metal concentration in the surface sediment of Tanjung Lumpur mangrove forest, Kuantan, Malaysia," Sains Malaysiana, vol. 40, no. 2, pp. 89-92, 2011.

[9] G. Redzwan, H. Abdul Halim, S. A. Alias, and M. M. Rahman, "Assessment of heavy metal contamination at west and east coastal area of peninsular Malaysia," Malaysian Journal of Science, vol. 33, no. 1, pp. 23-31, 2014.

[10] B. Y. Kamaruzzaman, M. C. Ong, and K. Y. S. Willison, "Distribution of heavy metals concentration in bottom sediment of terengganu river estuary, Terengganu, Malaysia," Sains Malaysiana, vol. 33, pp. 147-156, 2004.

[11] B. Y. Kamaruzzaman, A. Antonina, Z. Airiza, S. Syalindran, and M. C. Ong, "The geochemical profile of $\mathrm{Mn}, \mathrm{Co}, \mathrm{Cu}$ and $\mathrm{Fe}$ in Kerteh mangrove forest, Terengganu," Malaysian Journal of Analytical Sciences, vol. 11, no. 2, pp. 336-339, 2007.

[12] Y. Kamaruzzaman, W. A. Siti, M. C. Ong, and J. Bidai, "Spatial distribution of lead and copper in the bottom sediments of Pahang river estuary, Pahang, Malaysia," Sains Malaysiana, vol. 39 , no. 4 , pp. $543-547,2010$.

[13] D. L. Tomlinson, J. G. Wilson, C. R. Harris, and D. W. Jeffrey, "Problems in the assessment of heavy-metal levels in estuaries and the formation of a pollution index," Helgoländer Meeresuntersuchungen, vol. 33, no. 1-4, pp. 566-575, 1980.

[14] J. Usero, A. Garcia, and J. Fraidias, Calidad de las aguas y sedimentos del litoral Andaluz, Junta de Andalicia, Consejeria del Medio Ambiente, Sevilla, Spain, 2000.

[15] R. A. Sutherland, "Bed sediment-associated trace metals in an urban stream, Oahu, Hawaii," Environmental Geology, vol. 39, no. 6, pp. 611-627, 2000.

[16] P. Adamo, M. Arienzo, M. Imperato, D. Naimo, G. Nardi, and D. Stanzione, "Distribution and partition of heavy metals in surface and sub-surface sediments of Naples city port," Chemosphere, vol. 61, no. 6, pp. 800-809, 2005.

[17] G. Müller, "Index of geoaccumulation in sediments of the Rhine River," Geological Journal, vol. 2, pp. 108-118, 1969.
[18] K. Loska, D. Wiechulła, and I. Korus, "Metal contamination of farming soils affected by industry," Environment International, vol. 30, no. 2, pp. 159-165, 2004.

[19] K. M. Mohsin and M. I. Mohamed, Ekspedisi Matahari' 87: A Study on the Offshore Waters of the Malaysian EEZ, Occasional Publication no. 8, Universiti Pertanian Malaysia, 1988.

[20] A. Camerlengo and M. N. Saadon, "Dynamic behaviour of upper layers of the South China Sea," in Proceedings of the National Conference on Climate Change, pp. 135-140, Universiti Putra Malaysia, 1996.

[21] K. Wyrtki, "Physical oceanography of the Southeast Asian waters," NAGA Report 2, The University of California, Scripps Institution of Oceanography, La Jolla, Calif, USA, 1961.

[22] M. F. M. Akhirr and J. C. Yong, "Seasonal variation of water characteristics during inter-monsoon along the east coast of Johor," Journal of Sustainability Science and Management, vol. 6, no. 2, pp. 206-214, 2011.

[23] B. Y. Kamaruzzaman, Geochemistry or the marine sediments. Its paleoceanographic significance [Ph.D Thesis], Hokkaido University, Sapporo, Japan, 1999.

[24] S. K. Noriki, T. Nakanishi, M. Fukawa, T. Uematsu, H. Uchida, and S. Tsunogai, "Use of a Teflon vessel for the decomposition followed by determination of chemical constituents of various marine samples," Bulletin Faculty of Fisheries, Hokkaido University, vol. 31, pp. 354-465, 1980.

[25] P. Blaser, S. Zimmermann, J. Luster, and W. Shotyk, "Critical examination of trace element enrichments and depletions in soils: As, $\mathrm{Cr}, \mathrm{Cu}, \mathrm{Ni}, \mathrm{Pb}$, and $\mathrm{Zn}$ in Swiss forest soils," Science of the Total Environment, vol. 249, no. 1-3, pp. 257-280, 2000.

[26] C. Reimann and P. de Caritat, "Intrinsic flaws of element enrichment factors (EFs) in environmental geochemistry," Environmental Science and Technology, vol. 34, no. 24, pp. 5084-5091, 2000.

[27] K. C. Schiff and S. B. Weisberg, "Iron as a reference element for determining trace metal enrichment in Southern California Coastal shelf sediments," Marine Environmental Research, vol. 48, no. 2, pp. 161-176, 1999.

[28] S. J. Schropp, F. G. Lewis, H. L. Windom, J. D. Ryan, F. D. Calder, and L. C. Burney, "Interpretation of metal concentrations in estuarine sediments of Florida using aluminum as a reference element," Estuaries, vol. 13, no. 3, pp. 227-235, 1990.

[29] L. W. Daesslé, J. D. Carriquiry, R. Navarro, and J. A. VillaescusaCelaya, "Geochemistry of surficial sediments from Sebastián Vizcaíno bay, Baja California,” Journal of Coastal Research, vol. 16, no. 4, pp. 1133-1145, 2000.

[30] T. Liaghati, M. Preda, and M. E. Cox, "Heavy metal distribution and controlling factors within coastal plain sediments, Bells Creek catchment, southeast Queensland, Australia," Environment International, vol. 29, no. 7, pp. 935-948, 2004.

[31] C. H. van der Weijden, "Pitfalls of normalization of marine geochemical data using a common divisor," Marine Geology, vol. 184, no. 3-4, pp. 167-187, 2002.

[32] J. Tajam and M. L. Kamal, "Marine environmental risk assessment of Sungai Kilim, Langkawi, Malaysia: heavy metal enrichment factors in sediments as assessment indexes," International Journal of Oceanography, vol. 2013, Article ID 482451, 6 pages, 2013.

[33] G. Müller, "Die Schwermetallbelastung der sediment des Neckars und seiner Nebenflusse: eine Bestandsaufnahme," Chemical Zeitung, vol. 105, pp. 157-164, 1981. 
[34] M. A. Hossain, N. M. Ali, M. S. Islam, and H. M. Z. Hossain, "Spatial distribution and source apportionment of heavy metals in soils of Gebeng industrial city, Malaysia," Environmental Earth Sciences, vol. 73, no. 1, pp. 115-126, 2015.

[35] L. Angelovičová and D. Fazekašová, "Contamination of the soil and water environment by heavy metals in the former mining area of Rudňany (Slovakia)," Soil and Water Research, vol. 9, no. 1, pp. 18-24, 2014.

[36] S. Abd, W. M. R. Idris, Z. Ali Rahman et al., "Heavy metals content in soil environment dan Dillenia Suffruticosa at Pelepah Kanan Mining Area," Journal e-Bangi, vol. 6, no. 1, pp. 1-16, 2011.

[37] A. A. Pereira, B. van Hattum, A. Brouwer, P. M. van Bodegom, C. E. Rezende, and W. Salomons, "Effects of iron-ore mining and processing on metal bioavailability in a tropical coastal lagoon," Journal of Soils and Sediments, vol. 8, no. 4, pp. 239-252, 2008.

[38] R. Chester, Marine Geochemistry, Academic Press, London, UK, 2000.

[39] G. R. W. Denton, B. G. Bearden, L. P. Concepcion, H. G. Siegrist, D. T. Vann, and H. R. Wood, "Contaminant assessment of surface sediments from Tanapag Lagoon, Saipan," Water and Environmental Research Institute of the Western Pacific, Technical Report 93, University of Guam, Mangilao, Guam, 2001.

[40] ATSDR, Toxicological Profile for Aluminum, US Department of Health and Human Services, Public Health Service, Atlanta, Ga, USA, 2008.

[41] S. H. Patterson, "Bauxite reserves and potential aluminium resources of the world," Geological Survey Bulletin, vol. 1228, 1967.

[42] W. Salomons and U. Forstner, Metals in the Hydrocycle, Springer, Berlin, Germany, 1984.

[43] M. W. Clark, D. M. McConchie, D. W. Lewis, and P. Saenger, "Redox stratification and heavy metal partitioning in Avicenniadominated mangrove sediments: a geochemical model," Chemical Geology, vol. 149, no. 3-4, pp. 147-171, 1998.

[44] N. Roney, V. Cassandra, M. Williams, M. Osier, and S. J. Paikoff, Toxicological Profile for Zinc, US Department of Health And Human Services Public Health Service Agency for Toxic Substances and Disease Registry, 2005.

[45] NAS, "Inorganic solutes," in Drinking Water and Health, vol. 1, pp. 205-229, National Academy of Sciences, National Academy Press, Washington, DC, USA, 1977.

[46] A. J. Horowitz and K. A. Elrick, "The relation of stream sediment surface area, grain size and composition to trace element chemistry," Applied Geochemistry, vol. 2, no. 4, pp. 437-451, 1987.

[47] F. Monaci and R. Bargagli, "Barium and other trace metals as indicators of vehicle emissions," Water, Air, and Soil Pollution, vol. 100, no. 1-2, pp. 89-98, 1997.

[48] C. Marchand, E. Lallier-Vergès, F. Baltzer, P. Albéric, D. Cossa, and P. Baillif, "Heavy metals distribution in mangrove sediments along the mobile coastline of French Guiana," Marine Chemistry, vol. 98, no. 1, pp. 1-17, 2006.

[49] W. Machado, M. Moscatelli, L. G. Rezende, and L. D. Lacerda, "Mercury, zinc, and copper accumulation in mangrove sediments surrounding a large landfill in southeast Brazil," Environmental Pollution, vol. 120, no. 2, pp. 455-461, 2002.

[50] J. Guigue, O. Mathieu, J. Lévêque et al., "Dynamics of copper and zinc sedimentation in a lagooning system receiving landfill leachate," Waste Management, vol. 33, no. 11, pp. 2287-2295, 2013.
[51] ATSDR, Toxicological Profile for Cobalt, U.S. Department of Health and Human Services, Public Health Service, Atlanta, Ga, USA, 2004.

[52] A. K. H. Wood, Z. Ahmad, N. A. M. Shazili, R. Yaakob, and R. Carpenter, "Geochemistry of sediments in Johor Strait between Malaysia and Singapore," Continental Shelf Research, vol. 17, no. 10, pp. 1207-1228, 1997.

[53] E. B. Saion, A. K. H. Wood, Z. A. Sulaiman, A. A. Alzahrany, M. S. Elias, and B. S. Wee, "Determination of heavy metal pollution in depth profile of marine sediment samples from the Strait of Malacca," Fresenius Environmental Bulletin, vol. 16, no. 10, pp. 1279-1287, 2007.

[54] K. H. Wedepohl, "The composition of the continental crust," Geochimica et Cosmochimica Acta, vol. 59, no. 7, pp. 1217-1232, 1995.

[55] S. Gao, T.-C. Luo, B.-R. Zhang et al., "Chemical composition of the continental crust as revealed by studies in East China," Geochimica et Cosmochimica Acta, vol. 62, no. 11, pp. 1959-1975, 1998.

[56] J. Valdés, G. Vargas, A. Sifeddine, L. Ortlieb, and M. Guiñez, "Distribution and enrichment evaluation of heavy metals in Mejillones Bay $\left(23^{\circ} \mathrm{S}\right)$, Northern Chile: geochemical and statistical approach," Marine Pollution Bulletin, vol. 50, no. 12, pp. 15581568, 2005.

[57] G. M. S. Abrahim and R. J. Parker, "Assessment of heavy metal enrichment factors and the degree of contamination in marine sediments from Tamaki Estuary, Auckland, New Zealand," Environmental Monitoring and Assessment, vol. 136, no. 1-3, pp. 227-238, 2008.

[58] J. K. Bentum, M. Anang, K. O. Boadu, E. J. Koranteng-Addo, and E. Owusu Antwi, "Assessment of heavy metals pollution of sediments from Fosu lagoon in Ghana," Bulletin of the Chemical Society of Ethiopia, vol. 25, no. 2, pp. 191-196, 2011.

[59] G. A. Birch, "Scheme for assessing human impacts on coastal aquatic environments using sediments," in Coastal GIS 2003, C. D. Woodcoffe and R. A. Furness, Eds., vol. 14 of Wollongong Papers on Maritime Policy, Centre for Maritime Policy, University of Wollongong, Wollongong, Australia, 2003.

[60] J. Zhang and C. L. Liu, "Riverine composition and estuarine geochemistry of particulate metals in China-weathering features, anthropogenic impact and chemical fluxes," Estuarine, Coastal and Shelf Science, vol. 54, no. 6, pp. 1051-1070, 2002. 

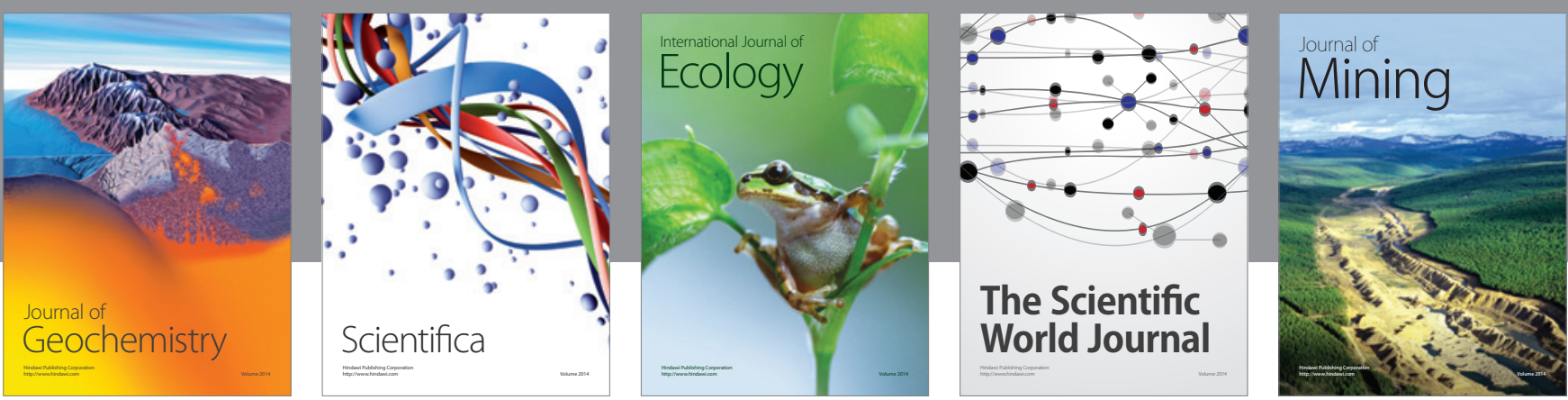

The Scientific World Journal
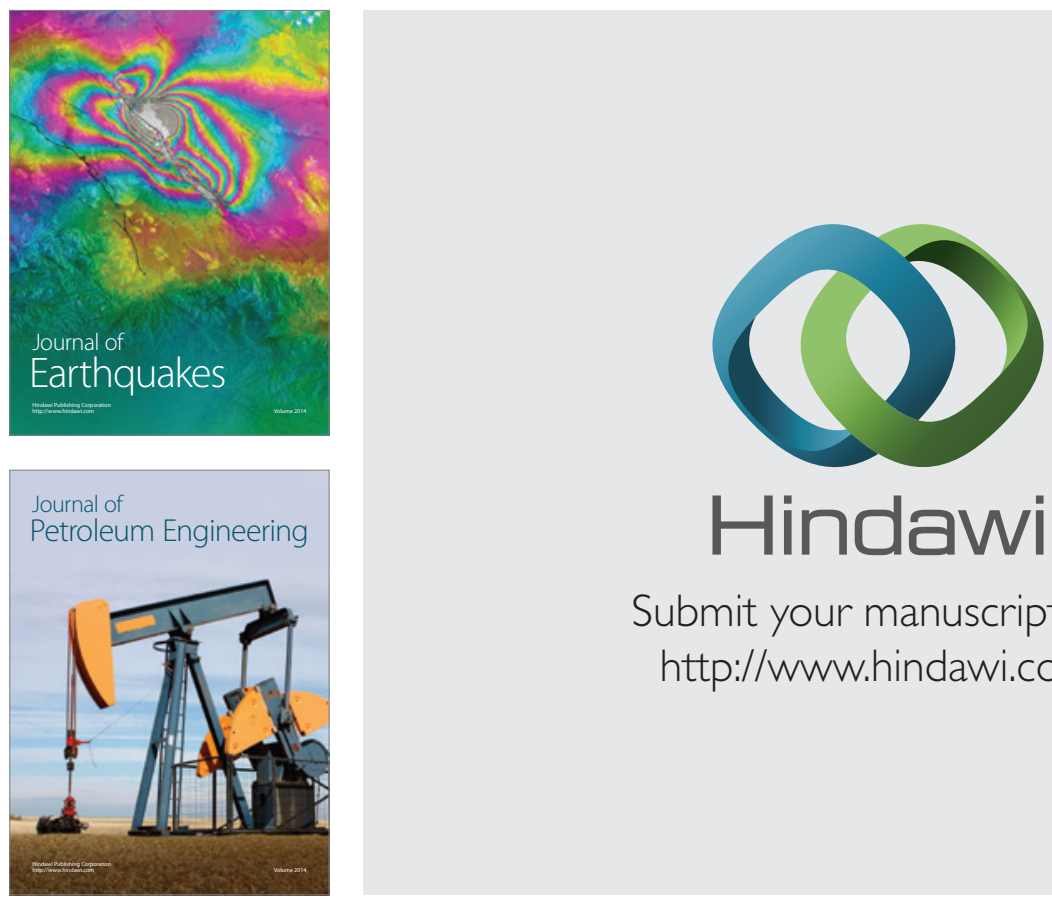

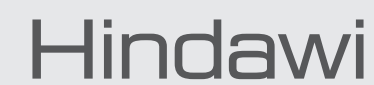

Submit your manuscripts at

http://www.hindawi.com
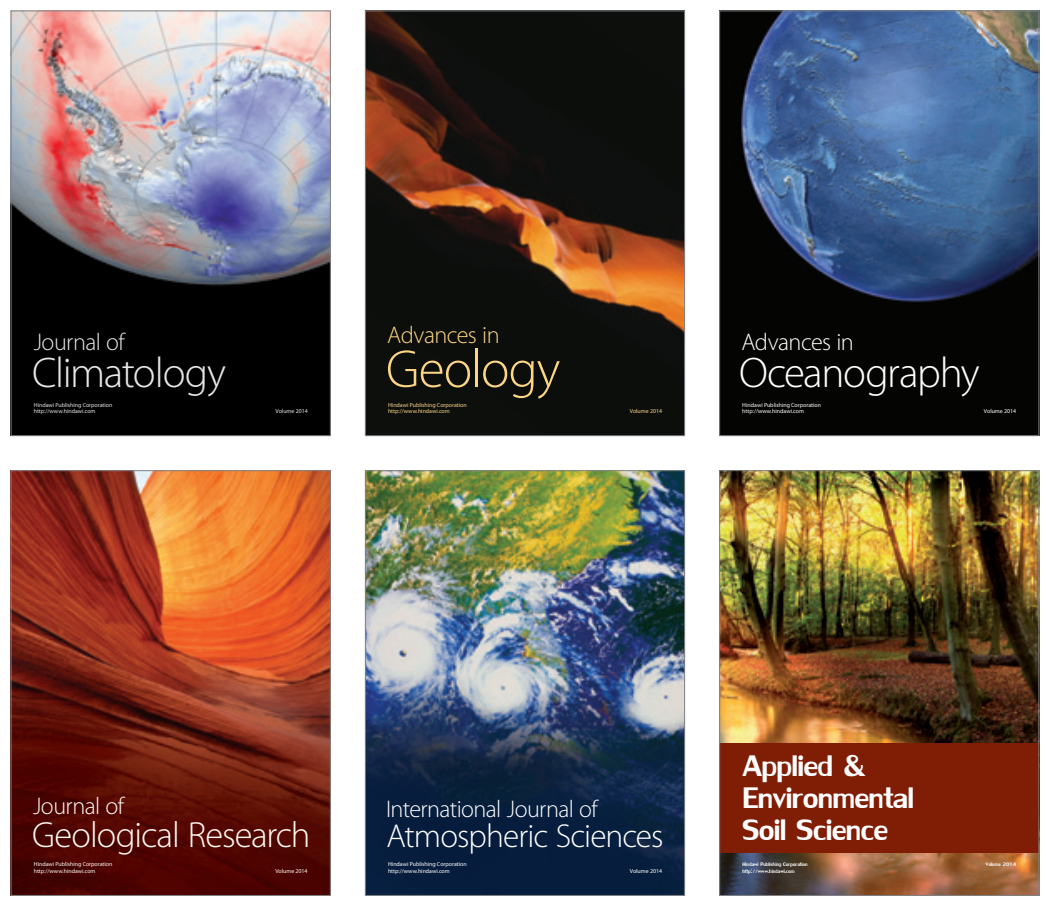
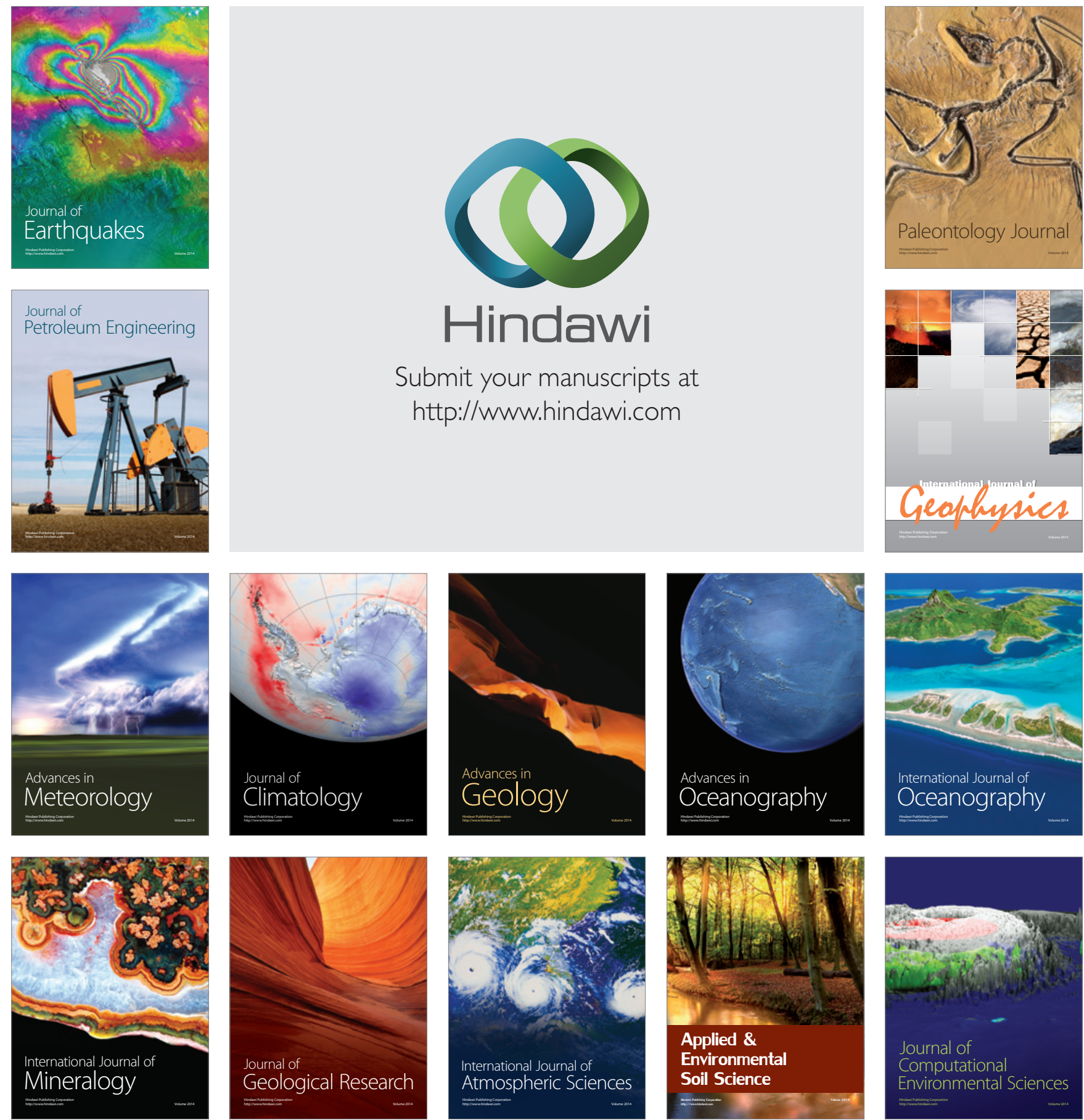